\title{
Transfer of Bacillus lentimorbus and Bacillus popilliae to the genus Paenibacillus with emended descriptions of Paenibacillus lentimorbus comb. nov. and Paenibacillus popilliae comb. nov.
}

\author{
Bertil Pettersson, ${ }^{1}$ Karen E. Rippere, ${ }^{2}$ Allan A. Yousten ${ }^{2}$ \\ and Fergus G. Priest ${ }^{3}$
}

Author for correspondence: Fergus G. Priest. Tel: +44 131451 3464. Fax: +44 1314513009. e-mail: f.g.priest@hw.ac.uk

\footnotetext{
1 Department of Biochemistry and Biotechnology, Royal Institute of Technology, S10044 Stockholm, Sweden

2 Biology Department, Virginia Polytechnic Institute and State University, Blacksburg, VA 24061, USA

3 Department of Biological Sciences, Heriot Watt University, Edinburgh EH14 4AS, UK
}

\begin{abstract}
Almost complete 16S rRNA gene sequences were generated for the type strains of the obligate insect pathogens Bacillus lentimorbus and Bacillus popilliae and a second strain of Bacillus popilliae (NRRL B-4081) received as 'Bacillus popilliae var. melolonthae'. A phylogenetic tree was constructed which grouped these strains into a well defined subcluster within the genus Paenibacillus. Bacillus popilliae NRRL B-4081 occupied an intermediate position between the type strains of Bacillus lentimorbus and Bacillus popilliae but with a marked clustering to the latter. The phylogenetic assignment of these strains to Paenibacillus is in contrast to earlier studies which placed these bacteria in the genus Bacillus, close to Bacillus subtilis. Indeed, the rRNA sequences generated in this study share less than $88 \%$ similarity to the deposited sequences for Bacillus popilliae ATCC $14706^{\top}$ and Bacillus lentimorbus ATCC $14707^{\top}$. The results obtained by using different tree algorithms, bootstrap analysis, branch lengths and verification by signature nucleotide analysis supported the reclassification of these species in the genus Paenibacillus as Paenibacillus lentimorbus comb. nov. and Paenibacillus popilliae comb. nov.
\end{abstract}

Keywords: Paenibacillus lentimorbus comb. nov., Paenibacillus popilliae comb. nov., insect pathogens, 16S rRNA

\section{INTRODUCTION}

Bacillus lentimorbus and Bacillus popilliae were first described by Dutky (1940) as the causative agents of milky disease in Japanese beetle and related scarab larvae (Klein \& Kaya, 1995). Although there have been suggestions in the past that Bacillus popilliae and Bacillus lentimorbus may be varieties of a single species, DNA hybridization and RAPD analysis have shown that the two taxa are closely related but distinct and appropriately placed in separate species (Rippere et al., 1998). Physiologically, differences between the species are few, but growth in the presence of vanco-

The GenBank accession numbers for the 16S rRNA gene sequences of Bacillus lentimorbus ATCC $14707^{\top}$, and Bacillus popilliae ATCC $14706^{\top}$ and NRRL B-4081 are AF071861, AF071859 and AF071860, respectively. mycin or $2 \% \mathrm{NaCl}$ is generally associated with strains of Bacillus popilliae (Rippere et al., 1998). The two species are responsible for slightly different forms of milky disease. Bacillus popilliae causes type A milky disease and Bacillus lentimorbus is associated with type B milky disease (Dutky, 1940). The latter is characterized by the appearance of brown clots which block the circulation of haemolymph in the larva and lead to gangrenous conditions in the affected parts (Stahly et al., 1992).

In a comparative analysis of $16 \mathrm{~S}$ RNA sequences of 51 species of the genus Bacillus, Ash et al. (1991) described five principal groups of strains of which two, rRNA groups 3 and 4 , have since been afforded generic status as Paenibacillus (Ash et al., 1993) and Brevibacillus (Shida et al., 1996), respectively. In this original study, the type strains of Bacillus popilliae and Bacillus 
lentimorbus were recovered in rRNA group 1, a large group containing the type species of the genus, Bacillus subtilis (Ash et al., 1991). However, Bacillus popilliae and Bacillus lentimorbus have numerous physiological and ecological traits in common with various species of Paenibacillus, including poor sporulation in vitro, swollen sporangia, a requirement for complex media, variable Gram stain reaction and lack of catalase (in common with Paenibacillus larvae subsp. larvae). Indeed, in a numerical analysis of phenotypic features Bacillus popilliae and Bacillus lentimorbus were recovered in a cluster with other paenibacilli associated with insects, including Paenibacillus larvae subsp. larvae and Paenibacillus larvae subsp. pulvifaciens (Priest et al., 1981). These physiological and ecological observations suggested to us that Bacillus popilliae and Bacillus lentimorbus may be misclassified in rRNA group 1 and are actually more closely related to the bacteria of the genus Paenibacillus. Here we report a phylogenetic analysis based on 16S rRNA sequences of the type strains of Bacillus popilliae (ATCC $14706^{\mathrm{T}}$ ) and Bacillus lentimorbus (ATCC $14707^{\mathrm{T}}$ ) and present data consistent with the transfer of these species to the genus Paenibacillus.

\section{METHODS}

Strains and growth conditions. The strains used are listed in Table 1. Although strain NRRL B-4081 has been designated 'Bacillus popilliae var. melolonthae', given its uncertain varietal status (Stahly et al., 1992; Rippere et al., 1998) we shall refer to it simply by its species name. Bacillus lentimorbus and Bacillus popilliae strains were grown in MYPGP agar and broth (Dingman \& Stahly, 1983) at $30^{\circ} \mathrm{C}$ and stored as described previously (Rippere et al., 1998). All other strains were grown on nutrient agar and broth at $37^{\circ} \mathrm{C}$.

Fatty acid analysis. Fatty acids were extracted from strains ATCC $14706^{\mathrm{T}}$ and ATCC $14707^{\mathrm{T}}$ by a single tube method as described by Mayberry \& Lane (1993). Following esterification, fatty acids were analysed by GC on a Hewlett Packard 5890 using a flame-ionization detector. Microbial Identification System software (Microbial ID) was used for analysis.
DNA preparation and amplification for identification. DNA was prepared from 1 litre MYPGP broth as described previously (Rippere et al., 1998). The specific primers PAEN515F (Shida et al., 1997) and PAEN862F were used in conjunction with a reverse primer (RNA1484R) to the distal end of the 16S rRNA gene (Table 2) in PCR amplifications for presumptive identification of strains of the genus Paenibacillus. As a control, the forward primer (RNA31F), which recognizes the proximal end of the 16S rRNA gene, was used. Amplification conditions for both reactions were denaturation at $94{ }^{\circ} \mathrm{C}$ for $5 \mathrm{~min}$ followed by 25 cycles of denaturation at $94{ }^{\circ} \mathrm{C}$ for $1 \mathrm{~min}$, annealing at $58^{\circ} \mathrm{C}$ for $1.5 \mathrm{~min}$ and extension at $72^{\circ} \mathrm{C}$ for $1.5 \mathrm{~min}$ followed by a final extension at $72{ }^{\circ} \mathrm{C}$ for $5 \mathrm{~min}$. Products were separated in $1.0 \%$ agarose gels in TAE buffer.

In vitro amplification of the 16S rRNA gene. The 16S rRNA gene from genomic DNA preparations of Bacillus lentimorbus ATCC $14707^{\mathrm{T}}$ and Bacillus popilliae strains ATCC $14706^{\mathrm{T}}$ and NRRL B-4081 was amplified with a pair of primers complementary to the regions close to the $5^{\prime}$ and the $3^{\prime}$ termini of the gene. Genomic DNA of the respective strain $(10 \mathrm{ng})$ was used for amplification with the primers RIT604 and RIT621B (Table 2). PCR products $(1 \mu 1)$ were subjected to two different semi-nested amplifications. The primers RIT604 and RIT390B were used in one of the amplifications and RIT388 and RIT621B (Table 2) were used in the second semi-nested reaction. Biotinylated PCR products, suitable for solid-phase DNA sequencing, were generated with $10 \mathrm{pmol}$ of each primer and the following thermocycling profile was used: denaturation at $96^{\circ} \mathrm{C}$ for $15 \mathrm{~s}$ and a combined primer annealing/extension step at $70{ }^{\circ} \mathrm{C}$ for $90 \mathrm{~s}$ was repeated 30 times. A final extension at $72{ }^{\circ} \mathrm{C}$ for $10 \mathrm{~min}$ was also used.

Direct solid-phase $16 \mathrm{~S}$ rDNA sequencing. Immobilization of the biotinylated PCR products followed by strand separation and template preparation were performed with superparamagnetic beads (Dynabeads M-280 Streptavidin; Dynal). The nucleotide sequences from both strands were determined by direct solid-phase DNA sequencing (Hultman et al., 1991, 1989) with ALFexpress (Amersham Pharmacia Biotech) as described previously (Pettersson et al., 1996a, b, c). The sequencing primers are listed in Table 2.

Comparison of 16S rRNA genes. The 16S rDNA sequences from the Bacillus popilliae and Bacillus lentimorbus strains determined in this study were checked against deposited $16 \mathrm{~S}$ rDNA sequences in non-redundant GenBank, EMBL and

Table 1. Bacterial strains used in the study

\begin{tabular}{|c|c|c|c|}
\hline Strain & $\begin{array}{l}\text { rRNA } \\
\text { group* }\end{array}$ & $\begin{array}{c}\text { Reaction with } \\
\text { Paenibacillus-specific PCR }\end{array}$ & Source/description \\
\hline Bacillus subtilis NCIMB $3610^{\mathrm{T}}$ & 1 & - & Priest et al. (1988) \\
\hline Bacillus sphaericus 2362 & 2 & - & Alexander \& Priest (1990) \\
\hline Paenibacillus alvei DSM $29^{\mathrm{T}}$ & 3 & + & Priest et al. (1988) \\
\hline Paenibacillus chibensis NRRL B-142 ${ }^{\mathrm{T}}$ & 3 & + & Shida et al. (1997) \\
\hline Bacillus lentimorbus ATCC $14707^{\mathrm{T}}$ & 3 & + & Rippere et al. (1998) \\
\hline Bacillus popilliae ATCC $14706^{\mathrm{T}}$ & 3 & + & Rippere et al. (1998) \\
\hline 'Bacillus popilliae var. melolonthae' NRRL B-4081 & 3 & + & Rippere et al. (1998) \\
\hline Brevibacillus borstelensis HRS 23 & 4 & - & De Silva et al. (1998) \\
\hline
\end{tabular}

* rRNA groups as defined by Ash et al. (1991). 
Paenibacillus lentimorbus comb. nov. and $P$. popilliae comb. nov.

Table 2. Primers used for PCR and DNA sequencing

\begin{tabular}{|lcll|}
\hline Primer* & Position ${ }^{\dagger}$ & & \multicolumn{1}{c|}{ Sequence (5'-3') $\$$} \\
\hline PAEN515F & $470-494$ & GCTCGGAGAGTGACGGTACCTGAGA & Application \\
PAEN862F & $842-862$ & TCGATACCCTTGGTGCCGAAGT & Paenibacillus-specific \\
RNA31F & $8-31$ & gcgcaagcttAGAGTTTGATCCTGGCTCAGGACG & Paenibacillus-specific \\
RNA1484R & $1507-1484$ & gcggatccTACCTTGTTACGACTTCACCCCA & PCR \\
604 & $11-35$ & USP-GTTYGATCCTRGCTCAGGAYIAACG & PCR \\
388 & $334-356$ & USP-CCARACTCCTACGGRAGGCAGC & PCR \\
390B & $939-917$ & CTTGTGCGGGYYCCCGTCAATTC & PCR \\
620B & $1542-1520$ & RSP-GAAAGGAGGTRWTCCAYCCSCAC & PCR \\
USP & & CGTTGTAAAACGACGGCCAG & Sequencing \\
631C & $534-519$ & ATTACCGCGGCKGCTG & Sequencing \\
538C & $800-818$ & GTAGTCCACGCCGTAAACG & Sequencing \\
390C & $939-917$ & CTTGTGCGGGYYCCCGTCAATTC & Sequencing \\
623C & $1184-1200$ & GGGGATGATGTCAARTC & Sequencing \\
624C & $1237-1220$ & GTAGYAYGTGTGWAGCCC & Sequencing \\
RSP & & CACAGGAAACAGCTATGACC & Sequencing \\
\hline
\end{tabular}

${ }^{*} \mathrm{~B}$ and $\mathrm{C}$ indicate that the actual oligonucleotide was labelled with a biotin and an indodicarbocyanine (Cy5), respectively.

$\dagger E$. coli numbering (Brosius et al., 1978).

¥USP and RSP indicate that the PCR primer has a handle at the $5^{\prime}$ end with the sequence of the universal sequencing primer and the reverse sequencing primer, respectively. Lower case letters at the 5' ends of RNA31F and RNA1484R indicate two flanking residues and six residues constituting endonuclease restriction sites previously used for cloning. $\mathrm{K}, \mathrm{R}, \mathrm{S}, \mathrm{W}$ and $\mathrm{Y}$ denote degenerate positions according to the IUB letter code. The ' $I$ ' in primer 604 denotes the presence of an inosine residue.

DDBJ databases by using the gapped BLAST option (Altschul et al., 1997), implemented as a sequence search tool at the home page of The National Center of Biotechnology Information (http://www.ncbi.nlm.nih.gov). Close relatives were retrieved and aligned with other relatives maintained at the Ribosomal Database Project (Maidak et al., 1996). A secondary structure of the 16S rRNA of Bacillus subtilis (Maidak et al., 1996) was used for proper alignment of stems and loops. The alignment was performed manually using GDE (Genetic Data Environment) software (Smith, 1992). The phylogenies were inferred by using programs contained in the Phylogenetic Inference Package, PHYLIP 3.51c (Felsenstein, 1993). Evolutionary distances were calculated by DNADIST, correcting for multiple base changes at single locations by the method of Jukes \& Cantor (1969). User trees based on the distance matrix were computed by the neighbour-joining method (Saitou \& Nei, 1987) using the NEIGHBOR program. Parsimony analysis was performed by using DNAPARS. The trees obtained from neighbour-joining and parsimony were analysed for stability by performing bootstrap analysis by using SEQBOOT in sets of 500 resamplings. Majority-rule consensus trees were computed from the user trees by using the CONSENSE program.

Nucleotide sequence accession numbers. The GenBank accession numbers for the 16S rRNA sequences of the reference strains used for comparison in this study are as follows: Alicyclobacillus acidocaldarius ATCC $27009^{\mathrm{T}}$, X60742; Alicyclobacillus cycloheptanicus DSM 4006 ${ }^{\mathrm{T}}$, X51928; Aneurinibacillus aneurinilyticus ATCC $12856^{\mathrm{T}}$, X60645; Aneurinibacillus migulanus ATCC $9999^{\mathrm{T}}$, D78462; Bacillus circulans ATCC 4513 ${ }^{\mathrm{T}}, \quad$ X60613; Bacillus megaterium IAM 13418, D16273; Bacillus methanolicus NCIMB 13114, X64465; Bacillus sp., X60622 (formerly Bacillus lentimorbus ATCC $\left.14707^{\mathrm{T}}\right)$; Bacillus sp., X60633 (formerly Bacillus popilliae ATCC $14706^{\mathrm{T}}$ ); Bacillus stearothermophilus ATCC $12980^{\mathrm{T}}$, X60640; Bacillus subtilis ATCC $6051^{\mathrm{T}}$, X60646; 'Bacillus tipchiralis' C-type, AF039408; Brevibacillus borstelensis NRRL NRS-818 ${ }^{\mathrm{T}}$, D78456; Brevibacillus brevis ATCC 8246 , X60612; Paenibacillus alginolyticus DSM 5050 ${ }^{\mathrm{T}}$, D78465; Paenibacillus alvei ATCC 6344 ${ }^{\mathrm{T}}$ X X7304; Paenibacillus amylolyticus NRRL B-377 ${ }^{\mathrm{T}}$, D85396; Paenibacillus apiarius NRRL NRS-1438 $8^{\mathrm{T}}$ U49247; Paenibacillus azotofixans NRRL B14372 ${ }^{\mathrm{T}}$, D78318; Paenibacillus chibensis NRRL NRS-142 ${ }^{\mathrm{T}}$, D85395; Paenibacillus chondroitinus DSM 5051 $1^{\mathrm{T}}$, D82064; Paenibacillus curdlanolyticus IFO 15724, D78466; Paenibacillus glucanolyticus DSM 5162 ${ }^{\mathrm{T}}$, D78470; Paenibacillus gordonae ATCC $29948^{\mathrm{T}}$, X60617; Paenibacillus illinoisensis NRRL NRS-1356 ${ }^{\mathrm{T}}$, D85397; Paenibacillus kobensis IFO 15729, D78471; Paenibacillus larvae subsp. larvae ATCC 9545 ${ }^{\mathrm{T}}$ X60619; Paenibacillus lautus NRRL NRS-666 ${ }^{\mathrm{T}}$, D78473; Paenibacillus macerans DSM 24 ${ }^{\mathrm{T}}, \quad \mathrm{X} 60624 ;$ Paenibacillus macquariensis NCTC 10419 , X60625; Paenibacillus pabuli DSM 3036 $6^{\mathrm{T}}$ X60630; Paenibacillus peoriae IFO $15541^{\mathrm{T}}$, D78476; Paenibacillus polymyxa IAM $13419^{\mathrm{T}}$, D16276; 'Paenibacillus' strain C-168, Y16129; 'Paenibacillus' strain T-168, Y16128; Paenibacillus thiaminolyticus JCM $8360^{\mathrm{T}}$, D78475; Paenibacillus thiaminolyticus JCM 7540, D88513; Paenibacillus validus DSM $3037^{\mathrm{T}}$, D78320.

\section{RESULTS AND DISCUSSION}

\section{Presumptive allocation of Bacillus lentimorbus and Bacillus popilliae to the genus Paenibacillus}

Two diagnostic oligonucleotide primers targeted to unique regions of the 16S rRNA gene of paenibacilli (Ash et al., 1993; Shida et al., 1996) were used in PCR reactions with template DNA from Bacillus lenti- 


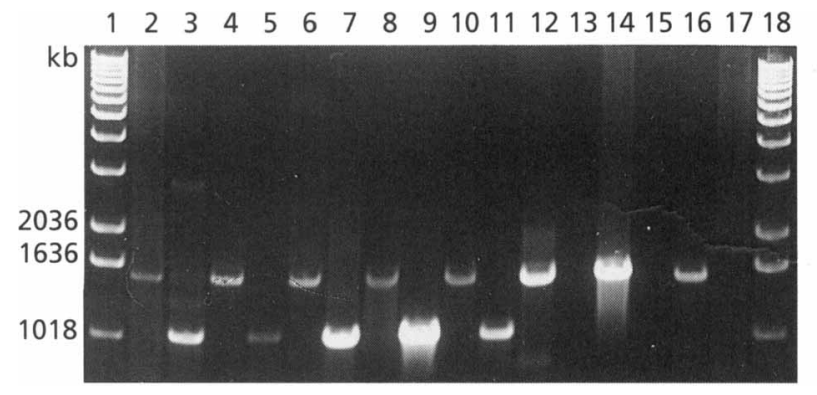

Fig. 1. Agarose gel electrophoresis of $P C R$ products generated with control primers (even lanes) and a Paenibacillus-specific primer (odd lanes) for various endospore-forming bacteria. Lanes: 1, size markers (1 kb ladder); 2 and 3, Paenibacillus alvei DSM $29^{\top} ; 4$ and 5 , Paenibacillus chibensis NRRL B-142 ${ }^{\top} ; 6$ and 7 , Bacillus popilliae ATCC $14706^{\top} ; 8$ and 9, Bacillus lentimorbus ATCC $14707^{\top} ; 10$ and 11, Bacillus popilliae NRRL B-408; 12 and 13, Bacillus subtilis NCIMB $3610^{\top} ; 14$ and 15 , Bacillus sphaericus 2362; 16 and 17, Brevibacillus borstelensis HRS 23; 18, size markers.

morbus ATCC $14707^{\mathrm{T}}$, Bacillus popilliae ATCC $14706^{\mathrm{T}}$ and NRRL B-4081, and representative strains of Bacillus, Brevibacillus and Paenibacillus (Fig. 1). The control reaction resulted in the predicted band of $1.5 \mathrm{~kb}$ in agarose gels of PCR products from all strains. However, when the specific primer PAEN515F was used, only the DNA from the Paenibacillus strains and from Bacillus lentimorbus and Bacillus popilliae acted as template, resulting in the predicted product of around $1 \mathrm{~kb}$ (Fig. 1). DNA was not amplified from Bacillus subtilis (rRNA group 1), Bacillus sphaericus (rRNA group 2) and Brevibacillus borstelensis (rRNA group 4) with this primer. This suggests that Bacillus lentimorbus and Bacillus popilliae are indeed members of the genus Paenibacillus and confirms the utility of this oligonucleotide as a diagnostic tool for strains of the genus Paenibacillus. Similar results (not shown) were obtained with the primer PAEN862F (Ash et al., 1993).

\section{5 rRNA gene sequences of Bacillus lentimorbus and Bacillus popilliae}

Direct solid-phase 16S rDNA sequencing resulted in virtually complete $(>95 \%)$ sequences of the $16 \mathrm{~S}$ rRNA genes of Bacillus popilliae ATCC $14706^{\mathrm{T}}$ (1470 nt) and NRRL B-4081 (1470 nt), and Bacillus lentimorbus ATCC $14707^{\mathrm{T}}$ (1479 nt). By using this procedure, the nucleotide sequence data of the $16 \mathrm{~S}$ rRNA genes belonging to different rRNA operons is determined simultaneously. In all cases both strands were sequenced and all positions were unambiguously determined. Interestingly, microheterogeneities (polymorphisms) in which two nucleotide residues share the same nucleotide position in different alleles, as described for Bacillus sporothermodurans, were detected for Bacillus popilliae ATCC $14706^{\mathrm{T}}$ and Bacillus lentimorbus ATCC $14707^{\mathrm{T}}$. These polymorphisms were situated in or close to the hypervariable regions V1 and
V2 (Gray et al., 1984) of the 16S rRNA molecule. This has also been found to be the case for other aerobic, endospore-forming bacteria, e.g. Bacillus sporothermodurans (Pettersson et al., 1996b) and Paenibacillus alginolyticus DSM $5050^{\mathrm{T}}$ (B. Pettersson, unpublished). In contrast, polymorphisms in the 16S rRNA genes of mycoplasmas have been found to be positioned in different parts of the $16 \mathrm{~S}$ rRNA molecule with no tendency for being concentrated in the V1 and V2 regions (Pettersson et al., 1996a, c, 1998).

The different nucleotides in a polymorphic position were present in roughly equal ratios (i.e. $1: 1$ ). The Bacillus popilliae ATCC $14706^{\mathrm{T}}$ rRNA genes contained three polymorphic sites $145(\mathrm{C} / \mathrm{T}), 173(\mathrm{~A} / \mathrm{T})$ and $258(\mathrm{G} / \mathrm{A})$ (unless otherwise stated Escherichia coli numbering is used; Brosius et al., 1978). Only one heterogeneous position was found in the 16S rRNA gene of Bacillus lentimorbus ATCC $14707^{\mathrm{T}}$, namely in the first nucleotide position of the tetra-loop starting at nt 208. Instead of the $G$ residue at this position, as commonly found in other Paenibacillus strains, the Bacillus lentimorbus ATCC $14707^{\mathrm{T}}$ rRNA gene contained an A and a T. Moreover, the stem of the actual helix was extended by five extra base pairs in Bacillus lentimorbus ATCC $14707^{\mathrm{T}}$. This higher order structural attribute was not found among any of the other members of the genus Paenibacillus for which $16 \mathrm{~S}$ rRNA gene sequence data could be retrieved, or indeed any other bacilli. Moreover, elongations of this region are present in only some of the other (eu)bacterial phyla (e.g. some Actinomyces and Actinopolyspora species, members of the Desulfotomaculum group and the $\beta$-, $\gamma$ - and $\delta$-subclasses of the Proteobacteria), however, without substantial similarity of primary structure. Therefore, this extension facilitates the identification of Bacillus lentimorbus by using a PCRbased strategy with one of the primers targeting the region between positions 202 and 215 with the sequence GTTCCGA(A/T)TAATCGGGGC (underlined residues are those involved in base pairing and bold type denotes the additional nucleotides explicitly found in the 16S rRNA molecule of Bacillus lentimorbus ATCC $14707^{\mathrm{T}}$ ). It is likely that this elongation is present in the matured $16 \mathrm{~S}$ rRNA molecule because it forms a stable stem structure containing canonical and non-canonical base pairs of the common $\mathrm{U} \cdot \mathrm{G}$ type (reviewed by Gutell et al., 1994) and because slight variations in stem lengths of the other helices in the $\mathrm{V} 2$ region of the molecule are known to exist in other taxa (Maidak et al., 1996). However, it remains to be shown by sequence analysis of more Bacillus lentimorbus strains if this extension is idiosyncratic for this species.

Previous studies have shown that the bidirectional solid-phase 16S rDNA sequencing technique results in highly accurate sequence data (e.g. Pettersson et al., 1994, 1996a, b, c). Therefore, the microheterogeneities discussed above are due to differences between the various rRNA genes rather than the result of sequencing artefacts. It has been claimed that $16 \mathrm{~S}$ 
rRNA gene sequences from different operons should be used for accurate phylogenetic inferences since different operon nucleotide sequences may result in altered tree topologies when closely related taxa are studied (Clayton et al., 1995; Pettersson et al., 1996b, 1998). However, because Bacillus popilliae ATCC $14706^{\mathrm{T}}$ and Bacillus lentimorbus ATCC $14707^{\mathrm{T}}$ only showed 3 and 1 polymorphic sites, respectively, the 16S rDNA sequences from individual operons will not significantly alter the evolutionary relationships presented in Fig. 2.

\section{Phylogenetic analysis of Bacillus lentimorbus ATCC $14707^{\top}$, and Bacillus popilliae ATCC $14706^{\top}$ and NRRL B-4081}

The phylogenetic tree shown in Fig. 2 is based on distance matrix analysis of aligned nucleotide positions ranging from nt 45 to 1430 of the 16S rRNA genes from the type strains and selected members of the genera Aneurinibacillus, Bacillus, Brevibacillus and Paenibacillus with Alicyclobacillus acidocaldarius ATCC $27009^{\mathrm{T}}$ as outgroup. Neither gaps nor ambiguously determined nucleotides were removed prior to computation of phylogenetic relationships for reasons to be detailed below. For comparison, trees were also constructed from differently corrected alignments by removing gapped positions and/or by omitting ambiguously aligned positions. These trees revealed no substantial changes in their overall topology from that shown in Fig. 2 which we judge to be representative with regard to phylogenetic stability. Moreover, topologies obtained by parsimony analysis strongly resembled those generated by neighbourjoining algorithms (not shown). The bootstrap percentage values included at the nodes of the tree attest to the stability of the main branches and it is reassuring that the tree is in overall agreement with a recently published dendrogram by Shida and co-workers (Shida et al., 1997).

All trees computed in this study revealed that Bacillus lentimorbus ATCC $14707^{\mathrm{T}}$, and Bacillus popilliae ATCC $14706^{\mathrm{T}}$ and NRRL B-4081 are members of a monophyletic group comprising the genus Paenibacillus. While this is in full agreement with phenetic studies (Gordon et al., 1973; de Barjac, 1981; Priest et al., 1981; Priest, 1994), it contrasts with earlier 16S rRNA sequence analyses (Ash et al., 1991) which placed the type strains of Bacillus lentimorbus and Bacillus popilliae (under the GenBank accession numbers X60633 and X60622, respectively) in rRNA group 1 close to Bacillus subtilis. Pairwise sequence comparisons indicated a distant relationship between the different sequences of the respective species, i.e. $<88 \%$ (not shown), which is reflected in the phylogenetic positions shown in bold type in Fig. 2. Thus, while our data suggest the reclassification of Bacillus popilliae ATCC $14706^{\mathrm{T}}$ and Bacillus lentimorbus ATCC $14707^{\mathrm{T}}$ as members of the genus Paenibacillus, rather than belonging to the Bacillus subtilis group, confusing results are likely to occur if appropriate $16 \mathrm{~S}$
rRNA gene sequences are not used for phylogenetic inferences. Since we have carefully checked our strains and they have been subjected to both phenotypic and molecular characterization (Rippere et al., 1998) we recommend that accession numbers AF071861 and AF071859 should be used for future studies of Bacillus lentimorbus and Bacillus popilliae, respectively, and that accession numbers X60633 and X60622 should represent two separate Bacillus strains.

Nucleotide motifs (signatures) in the 16S rRNA genes to assist identification of different groups within the family Bacillaceae were published by Ash et al. (1993). All signatures except nt position 845 (which we here correct to 844) continue to define the genus Paenibacillus in the light of the current study. While the vast majority of the Paenibacillus sequences have a $G$ residue at position 844 , members belonging to the two branches Paenibacillus apiarius/alvei and Paenibacillus curdlanolyticus/kobensis, all possessed an A at this site. Moreover, we have corrected one more position, namely the base pair $126 \cdot 236(\mathrm{~A} \cdot \mathrm{U})$ which should be $126 \cdot 235$ (A.U). Therefore, the signature nucleotide positions in the 16S rRNA molecule useful for the identification of Paenibacillus from other Bacillus rRNA groups and Alicyclobacillus involve the following positions: $126 \cdot 235(\mathrm{~A} \cdot \mathrm{U}), 157 \cdot 164(\mathrm{C} \cdot \mathrm{G})$, $458(\mathrm{G}), 493(\mathrm{G}), 494(\mathrm{~A}), 606(\mathrm{U}), 607(\mathrm{U}), 631$ (U), 632 (C), $852(\mathrm{G}), 867(\mathrm{~A}), 941 \cdot 1342(\mathrm{~A} \cdot \mathrm{U}), 948 \cdot 1233$ $(\mathrm{U} \cdot \mathrm{A}), 1252(\mathrm{C}), 1335(\mathrm{U})$ and $1423(\mathrm{~A})$. The sequence data of the 16S rRNA genes of Bacillus lentimorbus ATCC $14707^{\mathrm{T}}$ and Bacillus popilliae strains ATCC $14706^{\mathrm{T}}$ and NRRL B-4081 presented in this study harboured these motifs, supporting their association with the paenibacilli. These motifs were not present in the previously deposited nucleotide sequences for the type strains of these species.

The signatures are useful for the design of genusspecific oligonucleotides as shown in Fig. 1. We found both PAEN515F (Shida et al., 1997) and PAEN862F (Ash et al., 1993) valuable for identification of paenibacilli, although the latter sometimes gave rise to non-specific bands with some Bacillus species.

\section{The Paenibacillus lentimorbus/popilliae phylogenetic subcluster}

Bacillus lentimorbus ATCC $14707^{\mathrm{T}}$, and Bacillus popilliae ATCC $14706^{\mathrm{T}}$ and NRRL B-4081 were recovered in a subcluster of the Paenibacillus cluster consisting of eight taxa. This subgroup was obtained in all of the computed trees (represented by Fig. 2) and is regarded to be a stable phylogenetic entity as judged from bootstrap values and branch lengths. Hereafter, we will refer to this cluster as the Paenibacillus lentimorbus/popilliae cluster, since these species were the first described species belonging to this cluster.

The Paenibacillus lentimorbus/popilliae subcluster encompasses the parent species, and Paenibacillus 


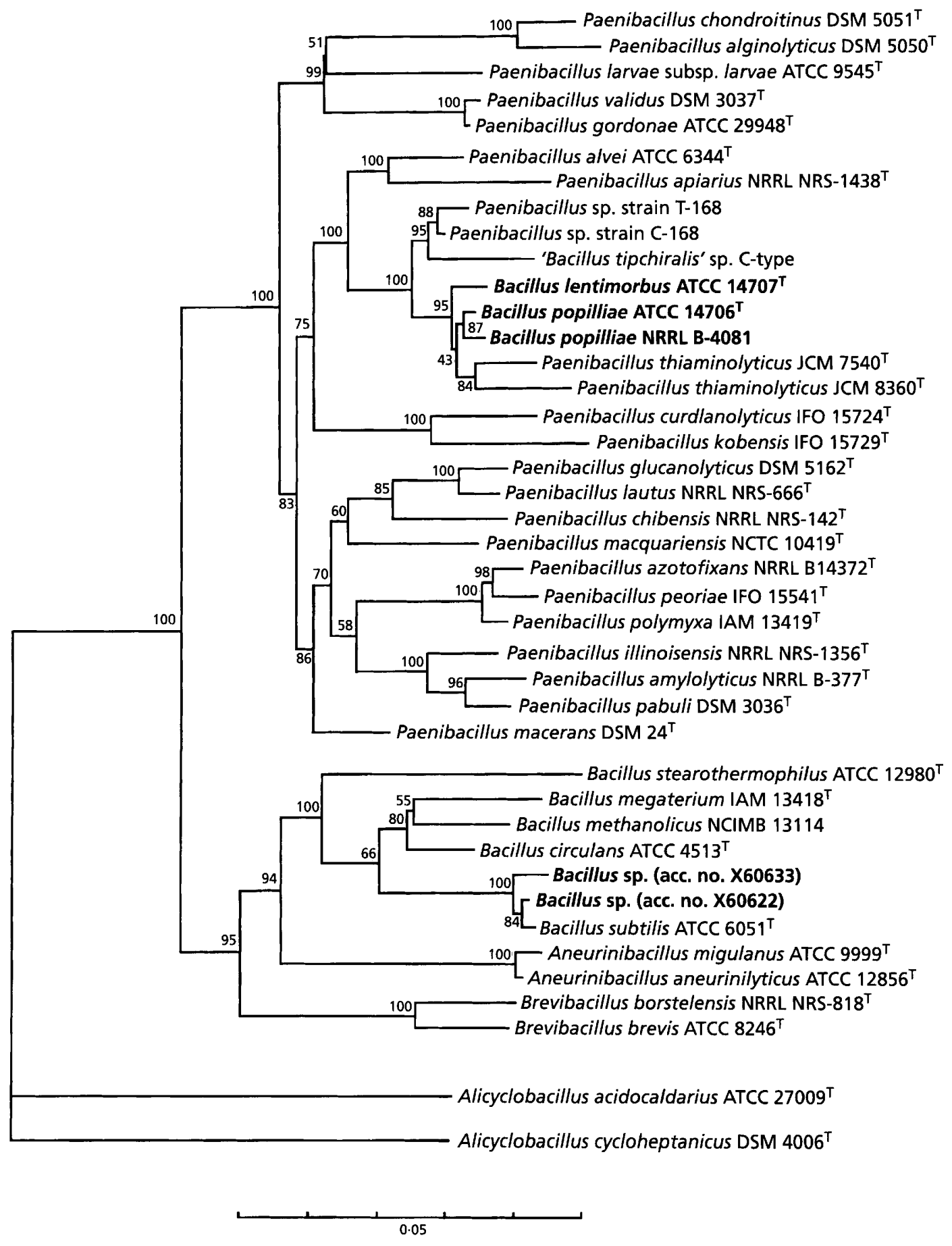

Fig. 2. Phylogenetic tree, based on neighbour-joining (Saitou \& Nei, 1987), derived from an alignment comprising 165 rRNA gene sequences, ranging from position 45 to 1430 (E. coli numbering; Brosius et al., 1978) from Paenibacillus species and selected members of closely related genera. Alicyclobacillus acidocaldarius ATCC $27009^{\top}$ served as outgroup. Bacillus lentimorbus ATCC $14707^{\top}$, and Bacillus popilliae ATCC $14706^{\top}$ and NRRL B-4081 are shown in bold type as are the previous phylogenetic positions obtained when using sequences deposited under the accession numbers $X 60622$ and X60633 for Bacillus lentimorbus ATCC $14707^{\top}$ and Bacillus popilliae ATCC $14706^{\top}$, respectively. The data set was resampled 500 times by using the bootstrap option and the percentage values are given at the nodes, showing the frequency at which the taxa to the right of the actual node cluster together. The scale bar indicates the number of substitutions per nucleotide position. 
Table 3. Unique nucleotide positions in the 16S rRNA molecule of the Paenibacillus lentimorbus/popilliae subcluster

Lower case letters indicate that the actual nucleotide residue was found in one of the 16S rRNA sequences of a strain or species of that group. Positions are given according to $E$. coli numbering (Brosius et al., 1978).

\begin{tabular}{|lcccc|}
\hline $\begin{array}{l}\text { Position of } \\
\text { base or pair }\end{array}$ & $\begin{array}{c}\text { P. lentimorbus/ } \\
\text { popilliae } \text { subcluster }\end{array}$ & $\begin{array}{c}\boldsymbol{P} \text {. apiarius/ } \\
\boldsymbol{P} \text {. alvei }\end{array}$ & $\begin{array}{c}\boldsymbol{P} \text {. curdlanolyticus/ } \\
\boldsymbol{P} \text {. kobensis }\end{array}$ & $\begin{array}{c}\text { Other } \\
\text { paenibacilli }\end{array}$ \\
\hline 121 & $\mathrm{U}$ & $\mathrm{C}$ & $\mathrm{C}$ & $\mathrm{C}$ \\
155 & $\mathrm{C}$ & $\mathrm{C}$ & $\mathrm{U}$ & $\mathrm{A} / \mathrm{U}$ \\
156 & $\mathrm{~A}$ & $\mathrm{~A} / \mathrm{C}$ & $\mathrm{U}$ & $\mathrm{C} / \mathrm{G} / \mathrm{U}$ \\
167 & $\mathrm{G}$ & $\mathrm{A}$ & $\mathrm{U}$ & $\mathrm{A} / \mathrm{g}$ \\
217 & $\mathrm{C}$ & $\mathrm{U}$ & $\mathrm{U}$ & $\mathrm{U} / \mathrm{c}$ \\
236 & $\mathrm{~A}$ & $\mathrm{G}$ & $\mathrm{G}$ & $\mathrm{G}$ \\
471 & $\mathrm{U} / \mathrm{c}$ & $\mathrm{C}$ & $\mathrm{C}$ & $\mathrm{C} / \mathrm{u}$ \\
593 & $\mathrm{G} / \mathrm{u}$ & $\mathrm{G}$ & $\mathrm{G}$ & $\mathrm{U}$ \\
\hline
\end{tabular}

thiaminolyticus JCM $8360^{\mathrm{T}}$ and JCM 7540 (Shida et al., 1997) which have no history of involvement with insects. Three other strains in this subcluster are 'Paenibacillus' C-168 and T-168 (GenBank Y16129 and Y16128, respectively) and 'Bacillus tipchiralis' (Rudner et al., 1998). The genus of the latter should be investigated since it conflicts with the monophyletic origin of the paenibacilli (e.g. Ash et al., 1993; Shida et al., 1997; Fig. 2) and the phylogenetic evidence points to it being a member of Paenibacillus. None of these bacteria are known to have close associations with insects (Rudner et al., 1998).

Signature nucleotide positions (compiled in Table 3) were determined for the subcluster which were characterized by nucleotide residues found only in the 16S rRNA genes of the taxa of this subcluster to the exclusion of all other paenibacilli. However, most of these nucleotide motifs were present in the highly variable V1 and V2 regions (Gray et al., 1984) of the 16S rRNA gene. The reason for this remains unclear, but might reflect that the members of the Paenibacillus lentimorbus/popilliae subcluster represent a recently evolved group of organisms.

Most closely related to the Paenibacillus lentimorbus/ popilliae subcluster are members of the Paenibacillus apiarius/alvei branch and the Paenibacillus curdlanolyticus/kobensis branch. While Paenibacillus alvei (Cheshire \& Cheyne, 1885) and Paenibacillus apiarius (Katznelson, 1955) were both isolated from dead honeybee larvae, neither is actually responsible for larval pathogenicity and Paenibacillus curdlanolyticus and Paenibacillus kobensis have no history of involvement with insects. It therefore seems that the only members of this part of the tree with entomopathogenic properties are Paenibacillus lentimorbus and Paenibacillus popilliae.

Paenibacillus larvae subsp. larvae is phenetically similar to Paenibacillus lentimorbus and Paenibacillus popilliae in being catalase-negative, unable to grow in nutrient broth and sporulating poorly, if at all, in vitro (Gordon et al., 1973;de Barjac, 1981; Stahly et al., 1992). This bacterium is responsible for 'American foulbrood' of honeybee larvae, a disease which is similar to the milky diseases of scarabaeid larvae and results from massive growth and sporulation of the bacteria in the larval haemolymph. It is therefore reassuring that the three endospore-forming, obligate entomopathogens should all be classified in Paenibacillus. The different phylogenetic placements (Fig. 2) may possibly reflect the evolutionary divergence of the insect hosts and the considerable time period in which the pathogens have been evolving separately.

\section{Phylogenetic relationships of Paenibacillus lentimorbus and Paenibacillus popilliae}

The fine relationships between Paenibacillus lentimorbus and Paenibacillus popilliae were determined from trees constructed from sequence alignments which were corrected by removing gaps and unsolved positions and from those in which such positions were included. The former grouped Paenibacillus popilliae NRRL B-8041 together with Paenibacillus lentimorbus ATCC $14707^{\mathrm{T}}$ rather than with the type strain of Paenibacillus popilliae ATCC $14706^{\mathrm{T}}$, while the latter showed the Paenibacillus popilliae strains with the closest similarity (Fig. 2). This indicated a certain instability in this part of the tree, the reason for which was further examined by carefully scrutinizing the alignment. The branch swapping was found to occur because some of the phylogenetically informative positions within the 16S rRNA gene sequences were deleted by gap removal to create the final data set to be used for subsequent phylogenetic calculations. The main problem was due to lack of compositional information in the primary structures of the actual positions in some of the operational taxonomic units. By comparing the $16 \mathrm{~S}$ rDNA sequences of Paenibacillus popilliae ATCC $14706^{\mathrm{T}}$ and NRRL B-4081, 
Table 4. Distinctive phenotypic properties of Paenibacillus lentimorbus, Paenibacillus popilliae and related paenibacilli

Data from Gordon et al. (1973), Priest et al. (1988), Shida et al. (1997) and Rippere et al. (1998). +, >90\% strains positive; $<10 \%$ strains positive; $v, 11-89 \%$ strains positive; NT, not tested.

\begin{tabular}{|c|c|c|c|c|c|c|c|c|c|}
\hline Character* & P. alvei & P. apiarius & P. curdlanolyticus & P. Kobensis & $\begin{array}{c}\text { P. larvae } \\
\text { subsp. larvae }\end{array}$ & $\begin{array}{l}\text { P. larvae subsp. } \\
\text { pulvifaciens }\end{array}$ & P. lentimorbus & P. popilliae & $\begin{array}{c}P . \\
\text { thiaminolyticus }\end{array}$ \\
\hline Spore shape & Oval & Oval & Oval & Oval & Oval & Oval & Oval & Oval & Oval \\
\hline Swollen sporangia & + & + & + & + & + & + & + & + & + \\
\hline Parasporal crystal & - & - & NT & NT & - & - & $\mathrm{v}$ & + & - \\
\hline Anaerobic growth & + & + & - & - & + & + & + & + & + \\
\hline Catalase & + & + & + & + & - & - & - & - & + \\
\hline Oxidase* & + & - & - & - & NT & - & - & - & + \\
\hline Nitrate reduction & - & + & + & + & $\mathrm{v}$ & $\mathrm{v}$ & - & - & + \\
\hline \multicolumn{10}{|l|}{ Acid from: } \\
\hline Arabinose & - & - & + & + & - & - & - & - & $\mathrm{v}$ \\
\hline Glucose & + & + & + & + & + & + & + & + & + \\
\hline Mannitol & - & - & - & - & - & + & - & - & - \\
\hline Xylose & - & - & + & + & - & - & - & - & - \\
\hline \multicolumn{10}{|l|}{ Production of: } \\
\hline Acetylmethylcarbinol & + & - & - & - & $\mathrm{v}$ & $\mathrm{v}$ & - & - & - \\
\hline Indole & + & - & - & - & + & + & - & - & + \\
\hline \multicolumn{10}{|l|}{ Decomposition of: } \\
\hline Tyrosine & $\mathrm{v}$ & + & NT & NT & - & - & - & - & + \\
\hline \multicolumn{10}{|l|}{ Hydrolysis of: } \\
\hline Casein & + & + & - & - & + & + & - & - & + \\
\hline Starch & + & + & + & + & - & - & - & - & + \\
\hline Use of citrate: & - & + & - & - & - & - & - & - & + \\
\hline \multicolumn{10}{|l|}{ Growth in: } \\
\hline Nutrient broth & + & + & + & + & - & + & - & - & + \\
\hline $2 \% \mathrm{NaCl}$ & + & + & NT & NT & + & + & + & - & + \\
\hline $5 \% \mathrm{NaCl}$ & $\mathrm{v}$ & + & - & - & - & - & $\mathrm{NT}$ & NT & $\mathrm{v}$ \\
\hline $0.001 \%$ Lysozyme & + & + & + & + & + & + & + & + & - \\
\hline \multicolumn{10}{|l|}{ Growth at: } \\
\hline $50^{\circ} \mathrm{C}$ & - & - & - & - & - & - & - & - & - \\
\hline pH 5.6 & - & + & NT & NT & - & - & - & - & - \\
\hline
\end{tabular}

* Based on reactions of type strains only for Paenibacillus lentimorbus and Paenibacillus popilliae.

and Paenibacillus lentimorbus ATCC $14707^{\mathrm{T}}$ with those from the other members of the Paenibacillus lentimorbus popilliae subcluster and the species of the neighbouring branches, a more detailed picture of the nucleotide similarity percentage values was thus obtained. The non-corrected similarity percentage values (not shown) obtained from this comparison indicated that Paenibacillus popilliae ATCC $14706^{\mathrm{T}}$ and NRRL B-4081 are indeed more closely related to each other than to Paenibacillus lentimorbus, revealing a $16 \mathrm{~S}$ rRNA gene similarity value of $99 \cdot 2 \%$ but showing $98 \cdot 6$ and $98.8 \%$, respectively, to Paenibacillus lentimorbus ATCC $14707^{\mathrm{T}}$. Therefore, the tree in Fig. 2 is most likely to be representative regarding the branching order between these strains. This conclusion is congruent with recent DNA-DNA reassociation experiments where Paenibacillus popilliae NRRL B-4081 showed $73-77 \%$ similarity to strains of Paenibacillus popilliae but only 59-61\% to strains of Paenibacillus lentimorbus (Rippere et al., 1998) and supports the varietal status for NRRL B-4081. However, further strains of this taxon must be isolated and characterized before any firm conclusions about subspecific classification can be entertained.

In conclusion, the results of this study revealed that the species Bacillus popilliae, represented by strains ATCC $14706^{\mathrm{T}}$ and NRRL B-4081, and Bacillus lentimorbus ATCC $14707^{\mathrm{T}}$ cluster tightly together in a highly defined subgroup within the genus Paenibacillus in accordance with their phenetic properties and we therefore propose transfer of these species to the genus Paenibacillus as Paenibacillus popilliae comb. nov. and Paenibacillus lentimorbus comb. nov. The phenotypic distinction of these species from phylogenetically and phenetically related taxa is given in Table 4.

\section{Emended description of Paenibacillus lentimorbus (Dutky 1940) comb. nov.}

Paenibacillus lentimorbus (len.ti.mor'bus. L. adj. lentus slow; L. n. morbus disease; M.L. n. lentimorbus the slow disease).

This description is based on this work and the studies of Dutky (1940), Gordon et al. (1973) and Rippere et al. (1998). Cells are rods, $0.5-0.7 \mu \mathrm{m}$ by $1.8-7 \mu \mathrm{m}$ which stain Gram-variable or -negative in exponentialphase cultures. Ellipsoidal spores are located centrally or terminally in swollen sporangia and may or may not be accompanied by a refractile parasporal body visible by phase-contrast microscopy. The type strain does not produce a parasporal body. May be isolated from haemolymph of infected larvae of the Japanese beetle (Popillia japonica Newman) and related larvae. Nutritionally fastidious, requires special media such as J-broth (Gordon et al., 1973) or MYPGP (Costilow \& Coulter, 1971). On these media forms colonies which are cream-coloured and less than $1 \mathrm{~mm}$ in diameter. 
Sporulation in laboratory media has not been reported. Spores are produced during in vivo growth in susceptible larvae. Maximum growth temperature is $35^{\circ} \mathrm{C}$, minimum is $20^{\circ} \mathrm{C}$. Facultative anaerobe, produces slight acidity ( $\mathrm{pH} 5.9-6.5)$ in VogesProskauer broth but negative reaction for acetoin. Acid is produced from fermentation of galactose, glucose, maltose, mannose and trehalose but not arabinose, mannitol or xylose. Grows in J-broth in presence of $0.001 \%$ lysozyme. The organism is negative for catalase and nitrate reduction reactions and fails to grow in the presence of $2 \% \mathrm{NaCl}$ (most strains) or $1 \mu \mathrm{g}$ vancomycin $\mathrm{ml}^{-1}$. Casein, gelatin and starch are not hydrolysed, indole is not produced and phenylalanine not deaminated. Predominant fatty acids of the type strain are: $\mathrm{C}_{15: 0}, 2 \cdot 7 \%$; iso- $\mathrm{C}_{15: 0}$, $6.6 \%$; anteiso- $\mathrm{C}_{15: 0}, 37 \% ; \mathrm{C}_{16}, 33 \%$ (results of duplicate assays). One strain that did not produce a paraspore had $90 \%$ DNA similarity to the type strain, whereas seven paraspore-forming strains had 73-78\% similarity to the type strain (Rippere et al., 1998). The type strain is ATCC $14707^{\mathrm{T}}$.

\section{Emended description of Paenibacillus popilliae (Dutky 1940) comb. nov.}

Paenibacillus popilliae (po.pil'li.ae. M.L. n. Popillia generic name of the Japanese beetle; M.L. gen. n. popilliae of Popillia).

This description is based on this work and the studies of Dutky (1940), Gordon et al. (1973) and Rippere et al. (1998). Cells are rods, $0 \cdot 5-0.8 \mu \mathrm{m}$ by $1 \cdot 3-5 \cdot 2 \mu \mathrm{m}$ which stain Gram-variable or -negative in exponentialphase cultures. Sporulating cells stain Gram-positive. Ellipsoidal spores are located centrally or terminally in swollen sporangia. The spore is often accompanied by a refractile parasporal body visible by phase-contrast microscopy. Isolated from haemolymph of infected larvae of the Japanese beetle (Popilliae japonica Newman) and related larvae such as the northern masked chafer (Cyclocephala borealis, Arrow). Nutritionally fastidious, requires special media such as MYPGP (Costilow \& Coulter, 1971) or J-broth (Gordon et al., 1973). On these media forms colonies which are cream-coloured and less than $1 \mathrm{~mm}$ in diameter. Sporulation in laboratory media is poor. Spores are produced during in vivo growth in susceptible larvae. Maximum growth temperature is $31{ }^{\circ} \mathrm{C}$, minimum is $20^{\circ} \mathrm{C}$. Facultative anaerobe, produces acid in Voges-Proskauer broth ( $\mathrm{pH} 5 \cdot 7-6 \cdot 2$ ) and grows in presence of $0.001 \%$ lysozyme in semisolid $\mathbf{J}$ agar. Negative for catalase and Voges-Proskauer reactions, does not grow in $5 \% \mathrm{NaCl}$ or nutrient broth. No acid from arabinose, mannitol or xylose. Casein, gelatin and starch are not hydrolysed. No production of indole or deamination of phenylalanine. Nitrate is not reduced. Most strains grow in the presence of $2 \% \mathrm{NaCl}$ or $150 \mu \mathrm{g}$ vancomycin $\mathrm{ml}^{-1}$. Acid is produced from glucose and trehalose. Predominant fatty acids of the type strain are: $\mathrm{C}_{15: 0}$, $6.8 \%$; iso- $\mathrm{C}_{15: 0}, 3 \cdot 2 \%$; anteiso- $\mathrm{C}_{15: 0}, 32 \% ; \mathrm{C}_{16}, 31 \%$ (results of duplicate assays). DNA reassociation: 24 strains showed greater than $73 \%$ similarity to the type strain (Rippere et al., 1998). The type strain is ATCC $14706^{\mathrm{T}}$.

\section{ACKNOWLEDGEMENTS}

We are grateful to Raja Mazumder for analysis of fatty acids.

Alexander, B. \& Priest, F. G. (1990). Numerical classification and identification of Bacillus sphaericus including some strains pathogenic for mosquito larvae. J Gen Microbiol 136, 367-376.

Altschul, S. F., Madden, T. L., Schaffer, A. A., Zhang, J., Zhang, Z., Miller, W. \& Lipman, D. J. (1997). Gapped BLAST and PSI-BLAST: a new generation of protein database search programs. Nucleic Acids Res 25, 3389-3420.

Ash, C., Farrow, J. A., Wallbanks, S. \& Collins, M. D. (1991). Phylogenetic heterogeneity of the genus Bacillus revealed by comparative analysis of small subunit ribosomal RNA sequences. Lett Appl Microbiol 13, 202-206.

Ash, C., Priest, F. G. \& Collins, M. D. (1993). Molecular identification of rRNA group 3 bacilli (Ash, Farrow, Wallbanks and Collins) using a PCR probe test. Antonie Leeuwenhoek 64, 253-260.

de Barjac, H. (1981). Insect pathogens in the genus Bacillus. In The Aerobic Endospore-forming Bacteria; Classification and Identification, pp. 241-250. Edited by M. Goodfellow \& R. C. W. Berkeley. London: Academic Press.

Brosius, J., Palmer, M. L., Kennedy, P. J. \& Noller, H. F. (1978). Complete nucleotide sequence of a $16 \mathrm{~S}$ ribosomal RNA gene from Escherichia coli. Proc Natl Acad Sci USA 75, 4801-4805.

Cheshire, F. R. \& Cheyne, W. W. (1885). The pathogenic history and history under cultivation of a new bacillus ( $B$. alvei), the cause of a disease of the hive bee hitherto known as foulbrood. $R$ Microsc Soc J Ser II 5, 581-601.

Clayton, R. A., Sutton, G., Hinkle, P. S., Jr, Bult, C. \& Fields, C. (1995). Intraspecific variation in small-subunit $r R N A$ sequences in GenBank: why single sequences may not adequately represent prokaryotic taxa. Int J Syst Bacteriol 45, 595-599.

Costilow, R. N. \& Coulter, W. H. (1971). Physiological studies of an oligosporogenous strain of Bacillus popilliae. Appl Microbiol 22, 1076-1084.

De Silva, S., Pettersson, B., Aquino de Muro, M. \& Priest, F. G. (1998). A DNA probe for the detection and identification of Bacillus sporothermodurans using the $16 \mathrm{~S}-23 \mathrm{~S}$ rDNA spacer region and phylogenetic analysis of some field isolates of Bacillus which form highly heat-resistant spores. Syst Appl Microbiol 21, 398-407.

Dingman, D.W. \& Stahly, D.P. (1983). Medium promoting sporulation of Bacillus larvae and metabolism of medium components. Appl Environ Microbiol 46, 860-869.

Dutky, S. R. (1940). Two new spore-forming bacteria causing milky disease in Japanese beetle larvae. J Agric Res 61, 57-68.

Felsenstein, J. (1993). PHYLIP (Phylogeny Inference Package) version 3.51c. Seattle: Department of Genetics, University of Washington.

Gordon, R. E., Haynes, W. C. \& Pang, C. H.-N. (1973). The Genus Bacillus. Agriculture Handbook no. 427. Washington, DC: United States Department of Agriculture. 
Gray, M. W., Sankoff, D. \& Cedergren, R. J. (1984). On the evolutionary descent of organisms and organelles: a global phylogeny based on a highly conserved structural core in small subunit ribosomal RNA. Nucleic Acids Res 12, 5837-5852.

Gutell, R. R., Larsen, N. \& Woese, C. R. (1994). Lessons from an evolving rRNA: $16 \mathrm{~S}$ and $23 \mathrm{~S}$ rRNA structures from a comparative perspective. Microbiol Rev 58, 10-26.

Hultman, T., Stăhl, S., Hornes, E. \& Uhlén, M. (1989). Direct solid phase sequencing of genomic and plasmid DNA using magnetic beads as solid support. Nucleic Acids Res 17, 4937-4946.

Hultman, T., Bergh, S., Moks, T. \& Uhlén, M. (1991). Bidirectional solid phase sequencing of in vitro-amplified plasmid DNA. BioTechniques 10, 84-93.

Jukes, T. H. \& Cantor, C. R. (1969). Evolution of protein molecules. In Mammalian Protein Metabolism, vol. 3, pp. 21-132. Edited by H. N. Munro. New York: Academic Press.

Katznelson, H. (1955). Bacillus apiarius, n. sp. an aerobic sporeforming organism isolated from honeybee larvae. $J$ Bacteriol 70, 635-636.

Klein, M. G. \& Kaya, H. K. (1995). Bacillus and Serratia species for scarab control. Mem Inst Oswaldo Cruz 90, 87-95.

Maidak, B. L., Olsen, G. J., Larsen, N., Overbeek, R., McCaughey, M. J. \& Woese, C. R. (1996). The Ribosomal Database Project (RDP). Nucleic Acids Res 24, 82-85.

Mayberry, R. W. \& Lane, J. R. (1993). Sequential alkaline saponification/acid hydrolysis/esterification: one tube method with enhanced recovery of both cyclopropane and hydroxylated fatty acids. $J$ Microbiol Methods 18, 21-23.

Pettersson, B., Johansson, K.-E. \& Uhlén, M. (1994). Sequence analysis of $16 \mathrm{~S}$ rRNA from mycoplasmas by direct solid phase DNA sequencing. Appl Environ Microbiol 60, 2456-2461.

Pettersson, B., Leitner, T., Ronaghi, M., Bölske, G., Uhlén, M. \& Johansson, K.-E. (1996a). Phylogeny of the Mycoplasma mycoides cluster as determined by sequence analysis of the $16 \mathrm{~S}$ rRNA genes from the two rRNA operons. $J$ Bacteriol 178, 4131-4142.

Pettersson, B., Lembke, F., Hammer, P., Stackebrandt, E. \& Priest, F. G. (1996b). Bacillus sporothermodurans, a new species producing highly heat-resistant endospores. Int J Syst Bacteriol 46, 759-764.

Pettersson, B., Uhlén, M. \& Johansson, K.-E. (1996c). Phylogeny of some ruminant mycoplasmas based on $16 \mathrm{~S}$ rRNA sequences and definition of a new cluster within the hominis group. Int $J$ Syst Bacteriol 46, 1093-1098.
Pettersson, B., Bölske, G., Thiaucourt, F., Uhlén, M. \& Johansson, K.-E. (1998). Molecular evolution within the subspecies Mycoplasma capricolum subsp. capripneumoniae as judged from polymorphisms in the $16 \mathrm{~S}$ rRNA genes. $J$ Bacteriol 180 , 2350-2358.

Priest, F. G. (1994). Systematics and ecology of Bacillus. In Bacillus subtilis and Other Gram-positive Bacteria: Biochemistry, Physiology and Molecular Genetics, pp. 3-16. Edited by J. A. Hoch, A. L. Sonenshein \& R. Losick. Washington, DC: American Society for Microbiology.

Priest, F. G., Goodfellow, M. \& Todd, C. (1981). The genus Bacillus: a numerical analysis. In The Aerobic Endosporeforming Bacteria: Classification and Identification, pp. 91-103. Edited by M. Goodfellow \& R. C. W. Berkeley. London: Academic Press.

Priest, F. G., Goodfellow, M. \& Todd, C. (1988). A numerical classification of the genus Bacillus. J Gen Microbiol 134, 1847-1882.

Rippere, K. E., Tran, M. T., Yousten, A. A., Hilu, K. H. \& Klein, M. G. (1998). Bacillus popilliae and Bacillus lentimorbus, bacteria causing milky disease in Japanese beetles and related scarab larvae. Int J Syst Bacteriol 48, 395-402.

Rudner, R., Martsinkevich, O., Leung, W. \& Jarvis, E. D. (1998). Classification and genetic characterization of pattern-forming bacilli. Mol Microbiol 27, 687-703.

Saitou, N. \& Nei, M. (1987). The neighbor-joining method: a new method for reconstructing phylogenetic trees. Mol Biol Evol 4, 406-425.

Shida, O., Takagi, H., Kadowaki, K. \& Komagata, K. (1996). Proposal for two new genera, Brevibacillus gen. nov. and Aneurinibacillus gen. nov. Int J Syst Bacteriol 46, 939-946.

Shida, O., Takagi, H., Kadowaki, K., Nakamura, L. K. \& Komagata, K. (1997). Transfer of Bacillus alginolyticus, Bacillus chondroitinus, Bacillus glucanolyticus, Bacillus kobensis and Bacillus thiaminolyticus to the genus Paenibacillus and emended description of the genus Paenibacillus. Int J Syst Bacteriol 47, 289-298.

Smith, S. (1992). GDE (Genetic Data Environment) version 2.2. Ann Arbor, MI: Millipore Imaging Systems.

Stahly, D. P., Andrews, R. \& Yousten, A. A. (1992). The genus Bacillus: insect pathogens. In The Prokaryotes, 2nd edn, pp. 1697-1745. Edited by A. Balows, H. G. Trüper, M. Dworkin W. Harder \& K.-H. Schleifer. New York: Springer. 